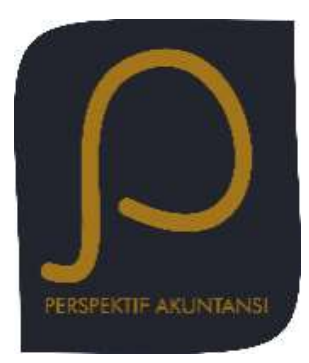

Perspektif Akuntansi

Volume 2 Nomor 1 (Februari 2019), hal. 39-51

ISSN: 2623-0194(Print), 2623-0186(Online) Copyright(C) The Authors(s). All Rights Reserved

Fakultas Ekonomika dan Bisnis,

Universitas Kristen Satya Wacana

DOI: https://doi.org/10.24246/persi.v2i1.p39-51

http://ejournal.uksw.edu/persi

\title{
Dampak Pengalihan PBB-P2 dan BPHTB Terhadap PDRB dan Belanja Modal
}

\author{
Dirgayany Pala'biran \\ Fakultas Ekonomika dan Bisnis Universitas Kristen Satya Wacana \\ Meyjerd Rombebunga ${ }^{1}$ \\ Fakultas Ekonomika dan Bisnis Universitas Kristen Satya Wacana
}
Received Abstract. This research aims to evaluate the impact of the diversion 20/12/2018 of PBB-P2 (Pajak Bumi dan Bangunan Pedesaan dan Perkotaan) and BPHTB (Bea Perolehan Hak Atas Tanah dan Bangunan) into Accepted regional tax on PDRB (Produk Domestik Regional Bruto) and Capital 01/02/2019 Expenditure in Regencies/Cities of Central Java Province. Secondary data is used and collected from Badan Pusat Statistik (BPS) of Central Java Province and Direktorat Jenderal Perimbangan Keuangan (DJPK) of Indonesia. Based on 35 Regencies/Cities in Central Java. This study uses data four years before and four years after the diversion to regional taxes in Regencies/Cities of Central Java Province, the result show that the PDRB and capital expenditure before the diversion is significantly different with the PDRB and capital expenditure after the diversion. It that the diversion improves regional economic and development.

Keywords: Capital expenditure, BPHTB, PBB, PDRB

Abstrak. Penelitian ini bertujuan untuk mengevaluasi dampak
pengalihan Pajak Bumi dan Bangunan Perdesaan dan Perkotaan
(PBB-P2) dan Bea Perolehan Hak atas Tanah dan Bangunan
(BPHTB) menjadi pajak daerah terhadap Produk Domestik
Regional Bruto (PDRB) dan Belanja Modal di Kabupaten/Kota
Provinsi Jawa Tengah. Penelitian ini menggunakan data sekunder
yang diperoleh dari Badan Pusat Statistik (BPS) Jawa Tengah dan
Direktorat Jenderal Perimbangan Keuangan (DJPK) Indonesia.
Dengan menggunakan 35 Kabupaten/Kota di Jawa Tengah.
Periode yang diambil adalah empat tahun sebelum dan empat
tahun sesudah pengalihan menjadi pajak daerah pada setiap 
Kota/Kabupaten di Jawa Tengah. Penelitian ini menunjukkan bahwa terdapat perbedaan PDRB dan belanja modal sebelum dan sesudah pengalihan PBB dan BPHTB menjadi pajak daerah. Hal tersebut bermakna bahwa pengalihan PBB dan BPHTB menjadi pajak daerah bermanfaat untuk meningkatkan perekonomian daerah dan menunjang pembangunan daerah.

Kata kunci: Belanja modal, BPHTB, PBB, PDRB

\section{Pendahuluan}

Indonesia menganut asas desentralisasi, di mana diberikan kesempatan kepada pemerintah daerah untuk mengatur otonomi daerahnya masing-masing (Prathiwi, Herawati, \& Sulindawati, 2015). Sebelum adanya pelimpahan otonomi daerah, pemerintah pusat bertanggung jawab mengurus semua kepentingan setiap daerah, sehingga terkadang ada beberapa daerah yang luput dari perhatian pemerintah pusat terkait dengan pendanaan (Antong, Duriani, \& Ramadhan, 2015). Konsekuensi yang diterima pemerintah daerah dari pelaksaan otonomi daerah ini adalah pemerintah berkewajiban menggali potensi-potensi yang merupakan sumber pendapatan, sehingga dapat meningkatkan pendapatan suatu daerah (Jaya \& Dwirandra, 2014). Selanjutnya, Machmud, Kawung, \& Rompas (2014) mengungkapkan bahwa prinsip otonomi yang nyata adalah sebuah prinsip yang menekankan mengenai urusan pemerintahan yang dilaksanakan, memliki potensi untuk terus berkembang dan bertumbuh sesuai dengan khas daerah masing-masing. Oleh karena itu, salah satu tindakan yang diambil pemerintah dalam rangka melaksanakan otonomi daerah adalah dengan mengeluarkan desentralisasi fiskal dalam bidang perpajakan yang diatur dalam Undang-Undang Nomor 28 Tahun 2009 mengenai Pajak Daerah dan Retribusi Daerah. Kebijakan ini diharapkan mampu meningkatkan PAD agar pendanaan daerah menjadi lebih baik (Soewardi \& Ananda, 2014).

Sebelum diterbitkannya UU No 28 Tahun 2009 mengenai Pajak Daerah dan Retribusi Daerah, pemerintah daerah hanya menerima tujuh jenis pajak yakni pajak hotel, pajak restoran, pajak hiburan, pajak penerangan jalan, pajak parkir, pajak reklame dan pajak pengambilan bahan galian Go.C. Namun, setelah adanya UU tersebut maka pemerintah daerah menerima empat jenis pajak tambahan yaitu pajak air tanah, pajak sarang burung wallet, PBB Pedesaan dan Perkotaan, dan Bea Perolehan Hak Atas Tanah dan Bangunan (Lestari, 2014).

Dalam pelaksanaannya PPB mencakup lima sektor yakni pertambangan, kehutanan, pertambangan, perkotaan dan perdesaan. Namun, berdasarkan UU No.28 Tahun 2009, hanya PBB Perdesaan dan Perkotaan saja yang dialihkan menjadi pajak daerah, selebihnya masuk ke dalam pendapatan pemerintah 
pusat. Setelah diterbitkannya Undang-Undang tersebut, maka seluruh kewenangan pemungutan PBB-P2 dan BPHTB diserahkan sepenuhnya kepada pemerintah daerah. Artinya, pemerintah daerah akan memperoleh penghasilan tambahan yang bersumber dari pajak (Lestari, 2014). Berdasarkan data Direktorat Jenderal Pajak (DJP), pemerintah Kabupaten/Kota hanya menerima 64,8 persen dari seluruh total penerimaan PBB-P2 saat dikelola oleh pemerintah pusat. Demikian pula dengan BPHTB, setiap daerah hanya memperoleh 64 persen. Namun, setelah adanya pengalihan, maka sepenuhnya akan masuk ke penerimaan Kabupaten/Kota, sehingga dapat meningkatkan PAD. Pengalihan Pengelolaan PBB-P2 pada prinsipnya dilaksanakan secara bertahap untuk seluruh wilayah Kabupaten/Kota yang ada di Indonesia, namun dengan berbagai pertimbangan, yang mana salah satunya adalah kesiapan daerah tersebut menerima pengalihan yang dimaksud (Fitri, 2014).

Peningkatan PAD semestinya berdampak terhadap perekonomian daerah. Hal ini sejalan dengan Nasution (2010) yang menyatakan bahwa faktor-faktor yang memengaruhi pertumbuhan PDRB yaitu PAD. Artinya, peningkatan PAD yang diakibatkan oleh adanya pemasukan baru dari pajak daerah terkait pengalihan PBB-P2 dan BPHTB yang semula merupakan pajak yang dipungut oleh pemerintah pusat kemudian dialihkan menjadi pajak daerah dapat menambah jumlah uang yang masuk ke kas daerah. Dengan demikian, harapan terwujudnya daerah yang mandiri dalam rangka memenuhi kebutuhannya terkait kegiatan produksi untuk menghasilkan output tanpa melibatkan pemerintah pusat dapat memajukan perekonomiannya.

Selanjutnya, penelitian yang dilakukan oleh Untung, Widyastuti, dan Suyanto, (2017) membuktikan secara empiris bahwa PAD memiliki pengaruh terhadap belanja daerah secara keseluruhan. Selanjutnya, Prathiwi et al. (2015) dalam penelitiannya menyatakan bahwa pemungutan pajak tentu akan mengurangi kekayaan wajib pajak, namun dengan adanya kewajiban tersebut, digunakan pemerintah untuk membiayai belanja-belanja negara di seluruh sektor dalam rangka untuk melaksanakan fungsi budgetairnya. Dengan adanya pengalihan PBB-P2 dan BPHTB yang semula adalah pajak pusat menjadi pajak daerah dapat meningkatkan PAD, sehingga diharapkan belanja modal ikut meningkat. Belanja modal merupakan belanja yang digunakan untuk pelayanan kepada masyarakat, seperti pelayanan kesehatan, pendidikan, transportasi dan kesejahteraan masyarakat (Mutiara, 2015). Dengan demikian, di kemudian hari tujuan dari kemandirian daerah akan tercapai dalam bidang pendanaan khususnya belanja modal. Salah satu provinsi yang menerapkan pengalihan PBB-P2 dan BPHTB menjadi pajak daerah adalah Provinsi Jawa Tengah.

Berdasarkan data BPS Provinsi Jawa Tengah, terbukti bahwa PAD Provinsi Jawa Tengah pada tahun 2012 (sebelum pengalihan) hanya mencapai 5,79 Triliun, 
sedangkan pada tahun 2013 (setelah pengalihan) naik menjadi 6,62 Triliun (https://jateng.bps.go.id). Hal ini ditopang melalui kenaikan pajak daerah sebelum dan sesudah pengalihan PBB-P2 dan BPHTB masing-masing sebesar 4,87 Triliun dan 5,48 Triliun. Peningkatan PAD yang ditopang melalui pajak daerah berarti Provinsi Jawa Tengah diharapkan dapat menggunakannya untuk membiayai belanja daerah khususnya untuk belanja modal dalam rangka meningkatkan perekonomian maupun pembangunan daerah.

Penelitian yang dilakukan oleh Lucky (2013) serta Juniawan dan Suryantini (2018) membuktikan bahwa PAD dan belanja modal memiliki hubungan yang positif. Temuan ini berarti belanja modal yang direalisasikan oleh pemerintah semakin tinggi karena PAD suatu daerah yang semakin tinggi. Selanjutnya, Adelina (2013) menemukan bahwa tingkat efektivitas penerimaan dari sektor PBB di Kabupaten Gresik sangat efektif dengan persentase lebih dari 100 persen. Artinya, pengalihan PBB-P2 yang menjadi salah satu bagian yang mampu menambah PAD berpengaruh terhadap peningkatan alokasi belanja modal pemerintah daerah. Selain itu, penelitian yang dilakukan oleh Sunarto dan Sunyoto (2016) menunjukkan bahwa pertumbuhan ekonomi daerah dipengaruhi positif dan signifikan oleh pajak daerah. Hasil tersebut berarti, peningkatan pajak yang masuk sebagai kas daerah dapat digunakan oleh pemerintah daerah untuk memajukan perekonomiannya. Di Jawa Tengah, pertumbuhan ekonomi pada tahun 2012 (sebelum pengalihan) sebesar 6,3 persen, sedangkan tahun 2013 (setelah pengalihan) mengalami penurunan menjadi 5,9 persen (https://jateng.bps.go.id). Namun, tingkat pertumbuhan ekonomi Jawa Tengah masih lebih baik dibandingkan secara nasional yaitu pada tahun 2013 hanya mencapai 5,6 persen saja. Hasil tersebut menunjukkan adanya pengalihan PBB-P2 dan BPHTB menjadi pajak daerah yang diharapkan dapat menopang pertumbuhan ekonomi suatu daerah. Oleh karena itu, penelitian ini bertujuan untuk mengevaluasi dampak dari pengalihan PBB-P2 dan BPHTB dari pajak pusat menjadi pajak daerah terhadap PDRB dan belanja modal di Provinsi Jawa Tengah.

\section{Telaah Pustaka}

\section{Pendapatan Daerah}

Menurut Undang-Undang Nomor 32 Tahun 2004 tentang Pemerintah Daerah, pendapatan daerah adalah semua hak daerah yang diakui sebagai penambah nilai kekayaan bersih dalam periode tahun anggaran yang bersangkutan. Dalam rangka melaksanakan kegiatan pemerintahan, daerah-daerah yang ada di Indonesia memiliki kewenangan untuk mengelola kegiatan pemerintahannya dalam rangka peningkatan efisiensi dan efektivitas penyelenggaraan kegiatan pemerintahan dan pelayanan kepada publik. Dalam mewujudkan cita-cita 
tersebut, setiap daerah membutuhkan berbagai sumber penerimaan (pendapatan) untuk menunjang segala kegiatan operasionalnya. Menurut Standar Akuntansi Pemerintah Nomor 71 Tahun 2010 yang termasuk sebagai sumber-sumber pendapatan daerah adalah Pendaptan Asli Daerah (PAD), Dana Perimbangan, dan Lain-lain Penerimaan yang Sah.

PAD merupakan penerimaan yang diperoleh daerah dari sumber-sumber dalam wilayahnya sendiri yang dipungut berdasarkan peraturan daerah sesuai dengan peraturan perundang-undangan yang berlaku. Selain itu, Machmud et al. (2014) juga mengatakan bahwa pendapatan daerah berasal dari dua sumber yakni dana pusat dan pendapatan asli daerah itu sendiri. Berdasarkan UndangUndang Nomor 12 Tahun 2008 sumber-sumber PAD yaitu hasil retribusi daerah yang secara sah, pajak daerah, hasil perusahaan milik daerah dan hasil pengelolaan kekayaan daerah, serta lain-lain pendapatan daerah yang sah.

\section{Pajak Daerah}

Pajak merupakan sumber pendapatan yang paling utama bagi suatu negara karena digunakan untuk membiayai belanja negara dan memakmurkan masyarakat (Adelina, 2013). Penerimaan negara dari sektor pajak memegang peranan yang sangat penting untuk kelangsungan sistem pemerintahan suatu negara. Berdasarkan pemungutannya, pajak di Indonesia dibagi menjadi dua yaitu pajak pusat dan pajak daerah. Menurut Undang-Undang Nomor 32 Tahun 2004, hasil pajak daerah adalah pungutan yang dilakukan oleh pemerintah daerah berdasarkan peraturan perundang-undangan yang berlaku ditetapkan melalui peraturan daerah.

\section{PBB-P2 dan BPHTB}

PBB-P2 adalah pajak atas kawasan pemanfaatan bumi dan/atau bangunan oleh orang pribadi atau Badan. Sedangkan Bea Perolehan Hak atas Tanah dan Bangunan diartikan sebagai pajak atas perolehan hak atas tanah dan/atau bangunan.

Dalam rangka meningkatkan peneriman dari sektor perpajakan, maka pemerintah pusat melakukan amandemen Undang-Undang dalam perpajakan dan retribusi daerah (Widiastuti \& Laksito, 2014). Amandemen yang dikeluarkan pemerintah untuk membantu menopang PAD adalah UndangUndang Nomor 28 Tahun 2009 mengenai Pajak Daerah dan Retribusi Daerah. Dalam kebijakan tersebut PBB-P2 serta BPHTB dialihkan menjadi pajak daerah. Berdasarkan Undang-Undang Nomor 28 Tahun 2009, hanya PBB-P2 saja yang dialihkan menjadi pajak daerah, selebihnya masuk ke dalam pendapatan pemerintah pusat. 


\section{Pertumbuhan Ekonomi}

Produk Domestik Regional Bruto (PDRB) adalah indikator penting untuk mengetahui tingkat Pertumbuhan Ekonomi di suatu daerah dalam kurun waktu tertentu untuk mencapai kesejahteraan rakyat. PDRB atas dasar harga berlaku menggambarkan nilai tambah barang dan jasa yang dihitung menggunakan harga pada tahun berjalan (BPS, 2017). PDRB menurut harga berlaku dapat digunakan untuk mengetahui kemampuan sumber daya ekonomi, pergeseran, dan struktur ekonomi suatu daerah.

\section{Belanja Modal}

Menurut Standar Akuntansi Pemerintahan (2010), belanja modal merupakan pengeluaran dalam rangka menambah nilai aset tetap, termasuk biaya pemeliharaan yang sifatnya menambah nilai. Selain itu, belanja modal dapat dikategorikan dalam lima kategori utama: belanja modal tanah, belanja modal peralatan dan mesin, belanja modal gedung dan bangunan, belanja modal jalan, irigasi dan jaringan, serta belanja modal fisik lainnya.

\section{Pengembangan Hipotesis}

\section{Pengalihan PBB-P2 dan BPHTB terhadap PDRB}

Pertumbuhan ekonomi biasanya ditunjukan melalui produksi atas barang dan jasa yang diukur dengan PDRB atas dasar harga berlaku. Salah satu faktor yang dapat mempengaruhi PDRB suatu daerah adalah pajak daerah (Juniawan \& Suryantini, 2018).

Adanya objek pajak baru berupa PBB-P2 dan BPHTB maka tentu saja dapat meningkatkan penerimaan daerah. Kemudian, penerimaan daerah salah satunya dapat dimanfaatkan untuk melakukan proses produksi sehingga menghasilkan output berupa barang dan jasa dalam rangka meningkatkan pertumbuhan ekonomi. Hal ini sejalan dengan Soewardi \& Ananda (2014), Nasution (2010), serta Mutiara (2015) menemukan pajak daerah berpengaruh positif dan signifikan terhadap pertumbuhan ekonomi. Artinya, pajak daerah memiliki peranan penting karena dapat digunakan sebagai modal untuk merangsang kegiatan ekonomi dan akan menghasilkan output, sehingga PDRB mengalami peningkatan. Demikian pula Sunarto \& Sunyoto (2016) menyatakan bahwa diterapkannya kebijakan ini diharapkan dapat meningkatkan perekonomian suatu daerah. Dengan demikian hipotesis dirumuskan sebagai berikut:

$\mathbf{H}_{1}$ : Pengalihan PBB-P2 dan BPHTB berpengaruh positif terhadap PDRB. 


\section{Pengalihan PBB-P2 dan BPHTB terhadap Belanja Modal}

Pembangunan suatu daerah merupakan tujuan utama dari sebuah daerah. Oleh karena itu, untuk mencapai tujuan tersebut pemerintah daerah membutuhkan dana yang tidak sedikit (Octovido, Sudjana, \& Azizah, 2014). Menurut Wenny (2012) pemerintah daerah harus terus dipantau pertumbuhannya untuk terus menggali kekayaan daerah dalam meningkatkan pendapatan asli daerahnya. Proses tersebut berarti pembangunan infrastruktur daerah akan memudahkan masyarakat untuk melakukan aktivitas sehari-hari dengan nyaman dalam rangka meningkatkan kesejahteraannya. Oleh karena itu, pemerintah daerah melakukan belanja modal dalam rangka pengalokasian dana yang diperoleh dari pendapatan daerah dengan membiayai kebutuhan masing-masing daerahnya.

Salah satu sumber utama yang dapat digunakan adalah pajak daerah. Imon, Sabijono, \& Mawikere (2017) mengatakan bahwa tujuan dari pengalihan PBBP2 dan BPHTB adalah untuk meningkatkan akuntabilitas dan kualitas pelayanan pemerintah daerah kepada wajib pajak. Dengan demikian, pengalihan tersebut dapat menambah PAD sehingga dapat menambah belanja pemerintah daerah khususnya belanja modal.

Hasil penelitian Sugiarthi \& Supadmi (2014) menemukan bahwa terdapat pengaruh antara PAD terhadap belanja modal. Temuan tersebut menunjukkan apabila PAD meningkat maka keuangan daerah juga akan meningkat, sehingga pemerintah daerah akan berinisiatif untuk terus menggali potensi-potensi daerah yang dimiliki. Selain itu, pemerintah daerah juga akan memberikan proporsi belanja modal yang besar untuk pembangunan. Hal ini sejalan dengan penelitian yang dilakukan oleh Juniawan \& Suryantini, (2018) yang menyatakan bahwa untuk setiap belanja modal pemerintah daerah harus dipergunakan untuk membiayai kepentingan masyarakatnya dan untuk pembangunan infrastruktur. Dengan demikian, hipotesis dirumuskan sebagai berikut:

$\mathbf{H}_{2}$ : Pengalihan PBB-P2 dan BPHTB berpengaruh positif terhadap belanja modal.

\section{Metoda}

Desain penelitian yang digunakan adalah menggunakan archival research dengan belanja modal diukur menggunakan realisasi belanja modal, sedangkan pertumbuhan ekonomi diukur menggunakan PDRB atas dasar harga berlaku pada 35 Kabupaten/Kota yang ada di Jawa Tengah. Sumber data diperoleh dari website resmi BPS Provinsi Jawa Tengah dan DJPK. 
Pengujian dalam penelitian ini menggunakan analisis uji beda. Analisis uji beda terhadap PDRB dan belanja modal didasarkan pada pengalihan PBB-P2 dan BPHTB empat tahun sebelum dan sesudah dari pajak pusat menjadi pajak daerah. Berlakunya pengalihan PBB-P2 pada 35 Kabupaten/Kota di Provinsi Jawa Tengah berbeda-beda, seperti Pati dan Jepara masing-masing dimulai pada tahun 2011 dan 2012.

Sedangkan Kabupaten Cilacap, Banyumas, Purbalingga, Kebumen, Purworejo, Wonosobo, Magelang, Boyolali, Klaten, Sukoharjo, Karanganyar, Grobogan, Blora, Rembang, Kudus, Demak, Semarang, Temanggung, Batang, Pekalongan, Pemalang, Kota Brebes, Magelang, Surakarta, Salatiga, Semarang, Pekalongan, dan Tegal dimulai sejak tahun 2013. Kemudian, Kabupaten Banjarnegara, Wonogiri, Sragen, Kendal dimulai sejak tahun 2014. Sedangkan pengalihan BPHTB pada 35 Kabupaten/Kota di Provinsi Jawa Tengah dimulai serentak pada tahun 2011.

Teknik analisis data menggunakan uji paired sample t-test. Uji beda paired sample t-test dilakukan untuk menemukan dampak setelah pengalihan PBB-P2 dan BPHTB menjadi pajak daerah. Selain itu hasil uji juga digunakan untuk melihat perbedaan sebelum dan sesudah pengalihan.

\section{Hasil dan Pembahasan}

\section{Hasil}

Pengujian statistik deskriptif perlu dilakukan terlebih dahulu untuk memberikan gambaran data dalam sebuah penelitian.

Tabel 1. Statistik Deskriptif

\begin{tabular}{llllll}
\hline & N & Minimum & Maximum & Mean & $\begin{array}{l}\text { Std. } \\
\text { Deviation }\end{array}$ \\
\hline \multicolumn{2}{l}{ Panel A - PDRB } & & & & \\
\hline PBB & 35 & 9552 & 2017 & 4021 & 3455 \\
BPHTB & 35 & 2352 & 7301 & 3283 & 1751 \\
\hline \multicolumn{2}{l}{ Panel B- Belanja Modal } & & & & \\
\hline PBB & 35 & -1964 & 2564 & 6542 & 4810 \\
BPHTB & 35 & -3027 & 1189 & 3659 & 2520 \\
\hline
\end{tabular}

Sumber: Data sekunder diolah

Pada Tabel 1 telah ditunjukkan bahwa jumlah Kabupaten/Kota yang diteliti adalah sebanyak 35, yaitu seluruh Kabupaten/Kota yang ada di Provinsi Jawa Tengah. Melihat dampak pengalihan PBB terhadap PDRB baik empat tahun sebelum maupun setelah pengalihan berada pada mean 4021 dengan nilai minimum 9552 dan nilai maksimum 2017 serta standar deviasi 3455. Tidak hanya PBB, namun BPHTB juga menunjukkan nilai mean sebesar 32835 dengan nilai minimum 2352 dan nilai maksimum 7301, serta standar deviasi 
1751. Untuk belanja modal, mean PBB menunjukkan nilai sebesar 6542 dengan nilai minimum -1964 dan maksimum 2564 serta standar deviasi 4810. Selain itu, BPHTB juga menunjukkan nilai minimum sebesar -3027 dan nilai maksimum adalah 1189, dengan mean 3659, serta standar deviasi 2520.

Selanjutnya penelitian ini akan melihat apakah dengan adanya pengalihan PBBP2 dan BPHTB menjadi pajak daerah, dapat memberikan dampak bagi PDRB dan belanja modal pada Kabupaten/Kota yang ada di Provinsi Jawa Tengah. Oleh karena itu akan dilakukan pengujian dengan menggunakan uji beda yaitu paired sample t-test. Berikut merupakan hasil pengujian dan pembahasan dengan analisis uji beda pada 35 Kabupaten/Kota yang ada di Provinsi Jawa Tengah.

\section{Pengujian dengan Uji Beda}

Pada Tabel 2 berdasarkan uji beda yang dilakukan, hasil pengujian menunjukkan perbedaan nilai rata-rata untuk PDRB dan Belanja Modal empat tahun sebelum dan empat tahun sesudah pengalihan PBB-P2 dan BPHTB menjadi pajak daerah. Nilai rata-rata empat tahun setelah adanya pengalihan PBB-P2 dan BPHTB menjadi pajak daerah lebih tinggi dibandingkan empat tahun sebelum pengalihan. Kemudian, berdasarkan Tabel 2, diketahui bahwa nilai untuk hasil pengujian paired samples test menunjukkan nilai $-6,883$ dengan nilai signifikansi 0,000 yang lebih kecil dari 0,05, sehingga terbukti bahwa terdapat perbedaan yang signifikan antara PDRB empat tahun sebelum pengalihan PBB-2 dengan PDRB sesudah pengalihan PBB-P2.

\section{Tabel 2. Hasil Uji Paired Sample T-Test}

\begin{tabular}{llll}
\hline & \multicolumn{3}{c}{ Paired Samples Test } \\
\hline Panel A - PDRB & Mean & t & Sig (2-tailed) \\
\hline 4 Tahun sebelum pengalihan PBB & 6961 & -6.883 & 0.000 \\
4 Tahun setelah pengalihan PBB & 1098 & & \\
4 Tahun sebelum pengalihan BPHTB & 4558 & -6.689 & 0.000 \\
4 Tahun setelah pengalihan BPHTB & 9110 & & \\
\hline Panel B - Belanja Modal & & & \\
\hline 4 Tahun sebelum pengalihan PBB & 5353 & -8.045 & 0.000 \\
4 Tahun setelah pengalihan PBB & 1189 & & \\
4 Tahun sebelum pengalihan BPHTB & 4247 & -8.589 & 0.000 \\
4 Tahun setelah pengalihan BPHTB & 7906 & & \\
\hline
\end{tabular}

Sumber: Data sekunder diolah

Artinya, adanya pengalihan PBB-P2 menjadi pajak daerah memliki pengaruh terhadap tingkat PDRB di Provinsi Jawa Tengah. Kemudian, apabila dilihat dari 
nilai mean, jumlah PDRB empat tahun sesudah pengalihan PBB-P2 juga lebih besar dari pada sebelum pengalihan.

Hasil pengujian paired sample test data PDRB menunjukkan nilai -6.689 dengan nilai signifikansinya sebesar 0,000 dan nilai tersebut lebih kecil dari 0,05. Hal ini kembali menunjukkan bahwa terdapat perbedaan antara PDRB empat tahun sebelum pengalihan BPHTB dengan PDRB sesudah pengalihan BPHTB. Hasil tersebut menunjukkan dengan adanya pengalihan BPHTB menjadi pajak daerah, juga memliki dampak terhadap tingkat PDRB di Provinsi Jawa Tengah. Kemudian, dapat pula dilihat dari nilai mean, jumlah PDRB empat tahun sesudah pengalihan BPHTB lebih besar dibandingkan sebelum pengalihan BPHTB.

Dari hasil pengujian data belanja modal, menunjukkan nilai t sebesar -8.045 dengan nilai signifikansi 0,000 yang lebih kecil dari 0,05, sehingga terbukti bahwa terdapat perbedaan antara belanja modal empat tahun sebelum pengalihan PBB-2 dengan belanja modal sesudah pengalihan PBB-P2. Adanya pengalihan PBB-P2 menjadi pajak daerah memiliki dampak terhadap belanja modal pemerintah Provinsi Jawa Tengah. Apabila dilihat dari nilai mean, belanja modal empat tahun sesudah pengalihan PBB-P2 juga menunjukkan jumlah lebih besar dibandingkan sebelum pengalihan PBB-P2.

Belanja modal empat tahun sebelum dan sesudah pengalihan BPHTB menjadi pajak daerah juga terdapat perbedaan. Perbedaan tersebut dapat ditunjukkan dari hasil pengujian paired sample test dengan nilai -8.589 dan nilai signifikansi 0,000 yang lebih kecil dari 0,05. Hal ini berarti bahwa adanya pengalihan BPHTB menjadi pajak daerah, juga memliki dampak terhadap belanja modal pemerintah Provinsi Jawa Tengah. Kemudian berdasarkan nilai mean, belanja modal empat tahun sesudah pengalihan BPHTB menjadi pajak daerah juga kembali menunjukkan jumlah lebih besar dari pada empat tahun sebelum pengalihan BPHTB.

\section{Pembahasan}

Hasil penelitian dapat dilihat dari hasil uji beda terhadap data PDRB dan belanja modal di 35 Kabupaten/Kota di Jawa Tengah dengan menggunakan paired samples t-test. Berdasarkan pengujian yang dilakukan dapat disimpulkan bahwa PDRB empat tahun setelah adanya pengalihan PBB-P2 dan BPHTB dari pajak pusat menjadi pajak daerah lebih tinggi daripada sebelum adanya pengalihan. Hal serupa juga terjadi pada data belanja modal, yakni pendanaan setelah adanya pengalihan lebih besar dibandingkan dengan sebelum adanya pengalihan.

Berdasarkan hasil yang didapatkan, pengalihan PBB-P2 dan BPHTB menjadi pajak daerah memiliki dampak yang signifikan dalam meningkatkan 
pertumbuhan ekonomi dan menunjang pembangunan daerah Kabupaten/Kota di Provinsi Jawa Tengah. Pengalihan tersebut mampu meningkatkan pendapatan asli suatu daerah dari sektor pajak daerah, sehingga dapat digunakan untuk produksi dalam rangka meningkatkan pertumbuhan ekonomi.

Hasil tersebut sejalan dengan penelitian yang dikemukakan oleh Sunarto \& Sunyoto (2016), dan Nasution (2010) serta Soewardi \& Ananda (2014) yang mengatakan bahwa adanya pendapatan tambahan yang diperoleh dari sektor pajak daerah terkait pengalihan PBB-P2 dan BPHTB, mampu meningkatkan pendapatan suatu daerah sehingga akan digunakan untuk memajukan pertumbuhan ekonomi dan pembangunan daerah. Penelitian ini juga mendukung penelitian Mawarni, Sari, \& Abdullah (2013) yang menunjukkan bahwa dengan meningkatnya PAD suatu daerah, maka akan memiliki dampak yang signifikan terhadap pertumbuhan ekonominya.

Demikian pula dengan belanja modal, pengalihan PBB-P2 dan BPHTB memiliki dampak yang signifikan untuk menunjang pembangunan daerah. Hal ini sejalan dengan Jaya \& Dwirandra (2014) mengatakan bahwa dengan adanya pengalihan PBB-P2 dan BPHTB dapat meningkatkan pendapatan daerah, sehingga akan meningkatkan belanja modal yang pada akhirnya digunakan untuk pembangunan infrastruktur daerah. Selain itu, penelitian ini juga sejalan dengan penelitian yang dilakukan oleh Sugiarthi \& Supadmi (2014) yang menemukan bahwa meningkatnya PAD akan digunakan untuk membiayai belanja modal daerah tersebut.

\section{Simpulan}

Sesuai dengan hasil yang diperoleh, adanya pengalihan PBB-P2 dan BPHTB menjadi pajak daerah memiliki dampak yang signifikan terhadap PDRB dan belanja modal Kabupaten/Kota di Provinsi Jawa Tengah. Dengan demikian, penelitian ini menunjukkan bahwa pengalihan PBB-P2 dan BPHTB menjadi pajak daerah memiliki dampak positif bagi Kabupaten/Kota di Provinsi Jawa Tengah. Dalam penelitian ini, memiliki keterbatasan data yakni mengabaikan faktor lain yang dapat mempengaruhi PDRB dan belanja modal yaitu pajak Air Tanah dan Pajak Sarang Burung Wallet yang juga dialihkan menjadi pajak daerah.

\section{Daftar Pustaka}

Adelina, R. (2013). Analisis Efektifitas dan Kontribusi Penerimaan Pajak Bumi dan Bangunan (PBB) Terhadap Pendapatan Daerah Di Kabupaten Gresik. Jurnal Akuntansi Unesa, 1(2), 1-19. 
Antong, Duriani, \& Ramadhan, A. (2015). Pengaruh Pengelolaan Pajak Bumi dan Bangunan Perdesaan dan Perkotaan Tahun 2014 Terhadap Perencanaan Anggaran Penerimaan Pada DPPKAD Kota Palopo. Jurnal Akuntansi, 2(1), 10 15.

Fitri, K. (2014). Dampak Pengalihan Pengelolaan PBB-P2 Terhadap Penerimaan PBB Di Kelurahan Cinta Raja Kecamatan Sail Kota Pekanbaru. Jurnal Ekonomi Universitas Riau, 22(1), 1-10.

Imon, A. I., Sabijono, H., \& Mawikere, L. M. (2017). Evaluasi Pelaksanaan Pemungutan dan Prosedur Pencatatan Pajak Bumi dan Bangunan Perdesaan dan Perkotaan (PBB-P2) Di Kota Manado. Jurnal Riset Akuntansi Going Concern, 12(2), 44-51.

Indonesia, P. R. (2004). Undang-undang Nomor 32 Tahun 2004 Tentang Otonomi Daerah.

Indonesia, P. R. (2008). Undang-undang Nomor 12 Tahun 2008 Tentang Pemerintah Daerah.

Indonesia, P. R. (2009). Undang-undang Nomor 16 Tahun 2009 Tentang Ketentuan Umum Dan Tata Cara Perpajakan.

Indonesia, P. R. (2010). Peraturan Pemerintah Nomor 71 Tahun 2010 Tentang Standar Akuntansi Pemerintah.

Jaya, I. P. N. P. K., \& Dwirandra, A. A. N. B. (2014). Pengaruh Pendapatan Asli Daerah Pada Belanja Modal Dengan Pertumbuhan Ekonomi Sebagai Variabel Pemoderasi. E-Jurnal Akuntansi Universitas Udayana, 7(1), 79-92.

Juniawan, M. A., \& Suryantini, N. P. S. (2018). Pengaruh PAD, DAU dan DAK Terhadap Belanja Modal Kota dan Kabupaten Di Provinsi Bali. E-Jurnal Manajemen Unud, 7(3), 1255-1281.

Lestari, V. (2014). Analisis Pengaruh Pengalihan Pajak Bumi dan Bangunan Pedesaan dan Perkotaan (PBB P2) Terhadap Penerimaan Pendapatan Daerah Kota Kediri Tahun 2012 dan 2013. Jurnal Akuntansi Unesa, 3(1), 1-21.

Lucky, D. (2013). Analysis Of The Effect of Regional Financial Performance to Economic Growth and Poverty Through Capital Expenditure (Case Study of 38 Regencies/Cities In East Java Province). Journal of Economics and Sustainable Development, 4(19), 7-17.

Machmud, M., Kawung, G., \& Rompas, W. (2014). Analisis Kinerja Keuangan Daerah Di Provinsi Sulawesi Utara Tahun 2007-2012. Jurnal Berkala Ilmiah Efisiensi, 14(2), 1-13.

Mawarni, A. S., Sari, D., \& Abdullah, S. (2013). Pengaruh Pendapatan Asli Daerah dan Dana Alokasi Umum Terhadap Belanja Modal serta Dampaknya Terhadap Pertumbuhan Ekonomi Daerah (Studi Pada Kabupaten dan Kota Di Aceh). Jurnal Akuntansi, 2(2), 80-90.

Mutiara, D. J. (2015). Pajak Daerah dan Pengaruhnya terhadap PDRB di Propinsi Kalimantan Timur. Signifikan, 4(1), 95-99.

Nasution, H. S. (2010). Analisis Faktor-Faktor yang Mempengaruhi Pertumbuhan Produk Domestik Regional Bruto Era Desentralisasi Fiskal Di Propinsi Banten Periode 2001:1-2009:4. Media Ekonomi, 18(2), 29-48.

Octovido, I., Sudjana, N., \& Azizah, D. F. (2014). Analisis Efektivitas dan Kontribusi Pajak Daerah Sebagai Sumber Pendapatan Asli Daerah Kota Batu (Studi Pada Dinas Pendapatan Daerah Kota Batu Tahun 2009-2013). Administrasi Bisnis, 15(1), 1-7.

Prathiwi, I. A. M. A., Herawati, N. T., \& Sulindawati, N. L. G. E. (2015). Analisis Strategi Penerimaan Pajak Bumi dan Bangunan Pedesaan dan Perkotaan (PBB-P2) Serta Efektivitas Penerimaannya Di Pemerintah Kota Denpasar Tahun 20132014. E-Journal S1 Ak Universitas Pendidikan Ganesha, 3(1), 1-12. 
Soewardi, T. J., \& Ananda, C. F. (2014). Dinamika Pengelolaan BPHTB Setelah Dialihkan Menjadi Pajak Daerah. Jurnal Ilmiah Mahasiswa, 2(2), 1-14.

Statistika, B. P. (2017). Produk domestik regional bruto.

Sugiarthi, N. P. D. E. R., \& Supadmi, N. L. (2014). Pengaruh PAD, DAU, dan Silpa Pada Belanja Modal Dengan Pertumbuhan Ekonomi Sebagai Pemoderasi. E-Jurnal Akuntansi Universitas Udayana, 7(2), 477-497.

Sunarto, \& Sunyoto, Y. (2016). Pengaruh Pajak Daerah dan Retribusi Daerah Terhadap Kemandirian Daerah yang Berdampak Pada Pertumbuhan Ekonomi Daerah (Studi Empiris Pada Kabupaten dan Kota Di Jawa Tengah). Dharma Ekonomi, 23(43), 13-22.

Untung, J., Widyastuti, T., \& Suyanto. (2017). Pengaruh Pendapatan Asli Daerah, Dana Alokasi Umum, Dana Alokasi Khusus, Terhadap Belanja Daerah dan Dana Bagi Hasil Sebagai Pemoderasi Pemerintah Kabupaten/Kota Di Provinsi Jawa Barat Periode Tahun 2010-2014. Jurnal Ilmiah Widya Ekonomika, 1(2), 1-7.

Wenny, C. D. (2012). Analisis Pengaruh Pendapatan Asli Daerah (PAD) Terhadap Kinerja Keuangan Pada Pemerintah Kabupaten dan Kota Di Propinsi Sumatera Selatan. Forum Bisnis Dan Kewirausahaan Jurnal Ilmiah STIE MD, 2(1), 39-51.

Widiastuti, R., \& Laksito, H. (2014). Faktor-faktor Yang Mempengaruhi Kepatuhan Pajak Bumi Dan Bangunan (P-2) (Studi Pada WPOP Di Kabupaten Klaten). Diponegoro Journal of Accounting, 3(2), 1-14. 